\title{
A COMPARATIVE STUDY ON ICT AS A TOOL FOR THE EVALUATION OF THE POLICIES ON ICT IN EDUCATION
}

\author{
Gerard Doornekamp \\ Faculty of Educational Science and Technology \\ University of Twente, the Netherlands
}

Introduction

In our society information and communication technology (ICT) plays an important role. It is impossible to imagine life today without computers. Governments of most countries have understood this development and have realised the influence of ICT on the economy. Various departments have drawn up policy documents with regard to ICT. Those responsible for education have developed plans to implement ICT in schools at a great pace (Pelgrum \& Anderson, 1999). Children need to be prepared for this information and communication society. The idea is that it is never too early to make children familiar with this new technology. A lot of money is being spent to equip schools, teacher training and software development.

In light of all these efforts, the question arises whether this policy is successful. Policy-makers are interested in the state of affairs concerning the implementation of ICT in the schools. Taxpayers would like to know whether it is a well-considered decision and how money is spent. National monitoring systems provide policy makers with relevant information regarding the implementation of ICT and the obstacles in the process. Ministers of education can use this information to give account to the general public. In the Netherlands, for instance, these developments related to ICT in schools are monitored by the ICT-monitor. The ICT-monitor is a four-year project, aimed at continuously monitoring the developments of information and communication technologies in Dutch education as a 
result of the government action plan Investing in Staying Ahead and the note Education Online.

Policy makers are also interested in their position compared to other (surrounding) countries. They want to know whether they are at the same level of implementation or not. A lower level of implementation might have consequences for the economy. When there are less trained workers in the field of ICT, high-tech companies are not eager to invest money.

Policy makers make use of ICT benchmark publications in which the findings of several studies are summarised (e.g., ISI, 2001; RM G7, 1999). These publications give information on relevant indicators in a number of countries. However, they have some disadvantages, the most important of which is the source of information. They are based on studies which sometimes use different definitions of the same concept. This makes it difficult to compare results. Another disadvantage is that these benchmarks are published after the studies on which they are based. In the mean time, especially in the field of technology, many changes may have taken place, putting the benchmark publication out of date. Other, not unimportant disadvantages are concerned with the moment at which the data are collected in the original studies (which can be at different times) and differences between these studies (all indicators are not available in all studies).

These benchmark publications can be very useful but have several drawbacks, which make them less effective. An alternative is an international comparative study in which the same instruments are administered in many countries in the same period and where the collected data are centrally processed and analysed. An example in the field of technology is the Computers in Education study (Comped) of the International Association for the Evaluation of Educational Achievement (IEA). The goal of this study was to collect longitudinal and cross-national comparative data in order to contribute to the evaluation of policies on computers in the participating countries (Pelgrum \& Plomp, 1991; 1993). A special issue of Studies in Educational Evaluation in 1993, was devoted to the findings of this study.

Because of the rapid growth in technology and technological applications in education an update of the actual situation in education is required. However, a follow-up of this study (a second Computers in Education study) would not be appropriate since the introduction of the internet (also in schools). The technology is now information and communication technology (ICT). Therefore, the successor of Comped is called the Second Information Technology in Education Study (SITES), and it also includes the recent developments in ICT. The IEA launched this study in 1997. The currently running SITES project consists of three Modules. The first Module is a survey at school level in 27 countries.' In November 1999, the SITES-project published the final report of Module 1 (Pelgrum \& Anderson, 1999) in which the results of the participating countries are presented. Module 2 started in 1999 and will end in August 2002. In September 2000 the actual data collection started. Module 3 will be a statistical survey at school, teacher, and student level. This module started in 2000 and will end in 2005.

In this article the West-European countries, which participated in Module 1, are compared with each other on a number of indicators that were developed in the analysis of the data of Modulel and are ranked according to their position on the various indicators. In the description of the results, the focus is on the Netherlands. On the basis of the results of 
the Netherlands, compared with the results of other countries, and the ranking of the Netherlands, recommendations are made with regard to the ICT-policy of the Netherlands.

The focus of this article is on the Netherlands, but this should be regarded merely as an example. The comparison could also be made for any other country that participated in Module 1. That particular country could be compared with other countries participating in Module 1, which are relevant for that country. Conclusions could be drawn and policy recommendations be made for that particular country. The data are available in the final report of Module 1 (Pelgrum \& Anderson, 1999). First, a short description of the SITESproject is given. Then, an overview of policies on ICT in education of the Dutch government is presented. Next, five countries for primary education and six countries for lower secondary education are compared and ranked. The article ends with some conclusions and a discussion.

\section{The SITES Project}

The Second Information Technology in Education Study (SITES) is an international assessment of ICT in primary and secondary schools around the world. The SITES project consists of three Modules. Module 1 is a survey of school principals and technology coordinators at school level to give a description of the status of ICT in schools. This module started in 1997 and its final report was published in 1999.

Pelgrum and Anderson (1999) considered four elements to be the most essential in describing and comparing ICT-related activities in education. These elements are (a) curriculum, (b) infrastructure, (c), staff development, and (d) attitudes, policies and usage at managerial level. Important goals were (among others):

- To describe infrastructural ICT conditions (hardware/software), organisation and management, teaching staff qualifications, as well as the place of ICT in the school curriculum;

- To describe how ICT is used as object of learning (to acquire ICT related skills) and as a tool for realising particular educational objectives, especially the ones that are believed to be associated with the Learning Society.

The SITES project conducted a lengthy process to formulate a final version of two questionnaires. First, a list of indicators was drawn up in a meeting with the National Research Co-ordinators (NRCs). Next, items were collected from former studies regarding the use of computers in education. This collection of items was discussed with the NRCs. After a prepilot- and a pilot-test of the instruments, the final versions of the Principal Questionnaire and the Technical Questionnaire were discussed in a meeting with the NRCs.

In the SITES project, three populations were identified, namely Population 1 (target age 10 , in the eight month of the school year), Population 2 (target age 14, in the eight month of the school year) and Population 3 (final year of secondary education). Twentyseven countries provided information on available facilities, use and obstacles regarding ICT in representative samples of schools. The data collection of the SITES project took place in autumn 1998.

On the basis of this information a better insight into the current state-of-the-art technologies will be possible. This information will allow educational practitioners and 
policy makers to evaluate the current policy and to get a better understanding of the areas where intervention and additional support measures are needed.

\section{Policies on ICT in Education in the Netherlands}

Within the framework of the SITES project, each participating country prepared a document about the policies on ICT in their country. These documents were included in the final report (Pelgrum \& Anderson, 1999). Below, the contribution of the Netherlands to the report is summarised.

Since 1982, the Dutch government has applied a series of stimulation policies to promote the use of new technologies in education (Doornekamp \& Drent, 1999; Drent, Ten Brummelhuis, \& Plomp, in preparation). The stimulation policy was implemented by means of a number of promotion programs:

- The 100 Schools Project aimed at creating computer awareness and improving computer and information literacy.

- The INSP (Information Technology Stimulation Plan) program had two primary objectives: (a) to promote information and computer literacy and (b) to improve the quality of vocational education.

- In the OPSTAP [Moving On] project hardware acquisition and infrastructure measures were brought under the control of the Ministry, while courseware development, in-service training and the support of schools became the responsibility of the educational support organisations.

- The PRINT (Project Implementation New Technology) program evolved from the OPSTAP concept that a single development project should promote and implement the use of IT in the schools.

- The Enter: The Future project had the following outlook: (a) that any further implementation of IT in education would take place under the authority and responsibility of the schools. (b) that schools should be able to direct the integration of IT into their educational practices, (c) that IT in education no longer needed to be as much of a policy theme in itself, and (d) that the government wanted to take a more selective role toward IT in education.

In 1997 the government published the action plan Investing in Staying Ahead (MOC\&W. 1997). This plan was thought necessary because the described past investment and development programs had not led to the real integration of ICT into Dutch education. The development of the information society and the increasing importance of ICT demanded that schools familiarise children with ICT at an early age to prevent a gap between those who are and those who are not familiar with ICT. Another important aim of Investing in Staying Ahead was to use ICT as an engine for important educational innovations and higher standards in education. ICT was seen as a tool that came to facilitate individualised learning, independent learning and learning at one's own pace.

The government has increased its role in creating the right conditions for schools to integrate ICT in their education, because educational institutions do not seem to be able to successfully implement ICT themselves. However, the responsibility for the effective implementation of ICT stays with the schools themselves. The action plan Investing in 
Staying Ahead was followed by the note Education On-line (MOC\&W, 1999) and is an elaboration of the action plan. In Education On-line the policy goals for the period 1999 2002 are summed up focusing on four aspects:

1. Professionalism: New ways of teaching and learning influences the role of the teachers. Teachers will help the students to acquire knowledge and skills themselves. ICT can be used for this purpose. But ICT can also help to make the teaching profession more attractive by introducing new possibilities for co-operation and new teaching methods.

2. Educational software: New programs are needed for (a) core objectives and attainment targets in which ICT plays a role, (b) the promotion of new ways of teaching and learning like independent learning, problem solving and learning at one's own pace, (c) rich learning environments, and (d) planning, assessment and monitoring.

3. Management of the hardware: Safety is still insufficient. To tackle this problem the right decisions have to be made concerning the investments and expertise has to be used efficiently.

4. Kennisnet: All schools will be connected to an educational network, which also gives access to the Internet. Kennisnet provides several secure and controlled network services and is meant for schools, teachers, students and parents.

To be able to establish whether these goals have been achieved, the developments in the field of the use of computers are systematically and periodically assessed by means of the ICT-monitor. The ICT-monitor reports on the current state of affairs of ICT in education on an annual basis (Ten Brummelhuis, 1998a,b).

\section{Results}

\section{Introduction}

In this section the results of the Netherlands on several indicators are compared with six West-European countries: Finland, Norway, Denmark (only lower secondary education), United Kingdom (only items regarding hardware), France and Italy. In the Dutch national SITES-report the results of the Netherlands are compared with these and other countries (Doornekamp, 2000).

Similar to the final report of Module 1 of the SITES-project (Pelgrum \& Anderson, 1999), the results will be presented in four indicator-categories: (a) curriculum, (b) infrastructure, (c) staff development, and (d) attitudes, policies and usage at managerial level.

Because of the low response for Population 3 in the Netherlands, this population is left out in the tables in this paragraph. The tables show only the results of primary education (Population 1) and lower secondary education (Population 2).

After the final report of the SITES-project was published, results of school year 1998/1999 of the ICT-monitor became available (Ten Brummelhuis \& Drent, 2000; Ten Brummelhuis \& Slotman, 2000). Where possible, these data are included in the tables and figures to illustrate the developments in the Netherlands. 
The final section of this paragraph is devoted to the ranking of these countries. The procedure is described and the results are shown.

\section{Curriculum}
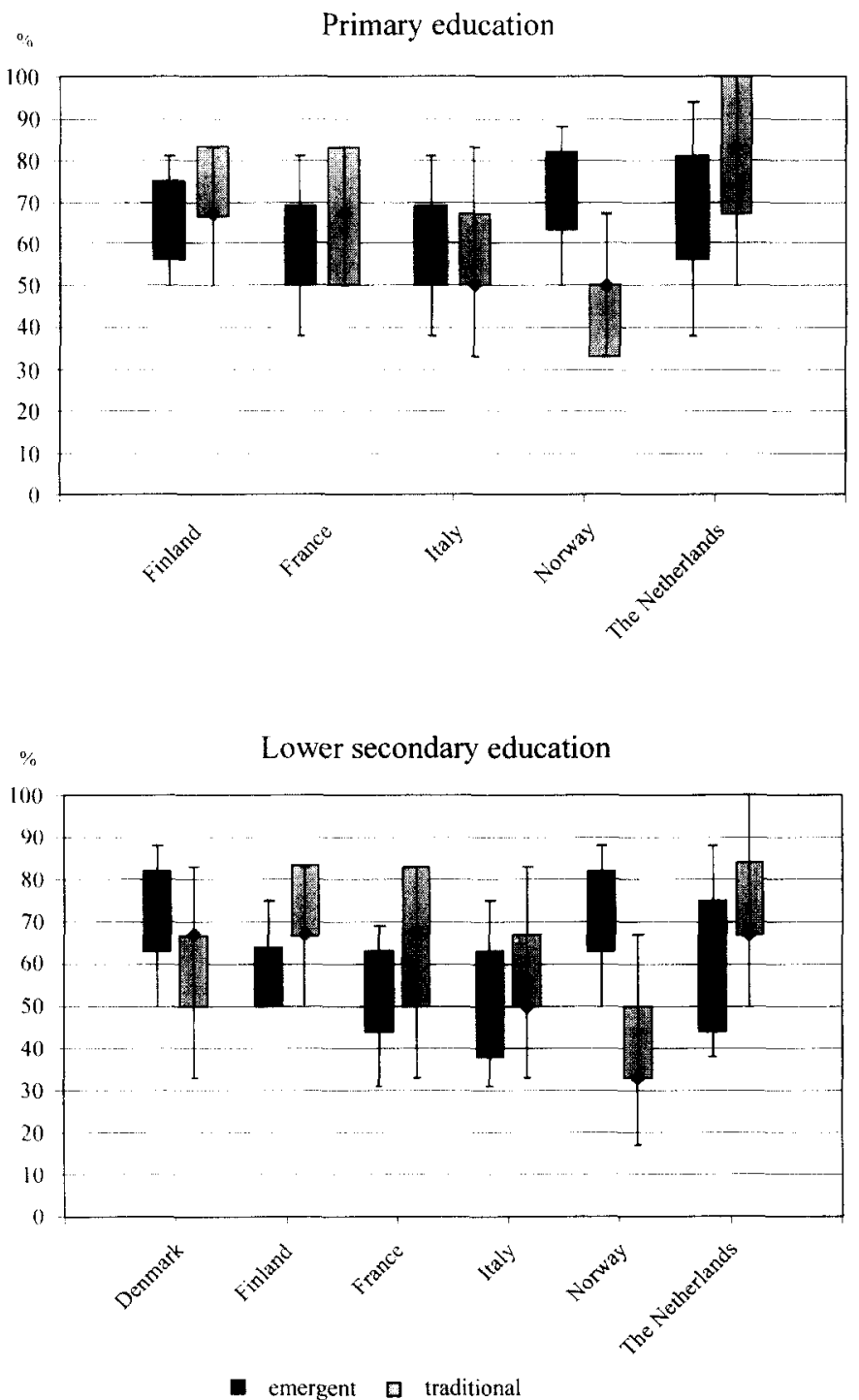

Notes: Boxes range from $25 \%$ lowest to $50 \%$ highest value; the diamonds in the boxes represents the median; tiles show values for $10 \%$ and $90 \%$ of the cases.

Figure 1: Box Plots of Indicators Concerning the Emergent and a Traditional Pedagogical Practice Paradigm for Primary and Lower Secondary Education 
The pedagogical practice paradigm of a school can be either emergent or traditional. Indicators for these practices can be used to establish whether ICT contributes to changes in education, which are related to the requirements of the information society.

In the Questionnaire a list with 13 aspects of education was drawn up. Principals were asked to indicate whether each of these aspects occurred in their school. On the basis of these data two indicators were calculated, one for each paradigm. The box-plot in Figure 1 shows the median and corresponding dispersion of the two indicators for each country. In many countries the traditional pedagogical practice was more prevalent than the emergent pedagogical practice, except for Denmark and Norway. In the Netherlands traditional practice also exceeded emergent practice.

To know which ICT-related objectives represent the policy of the school, the principals were asked to indicate at which, on a list of objectives, their school is aiming. The results for some objectives are shown in Table 1.

Table 1: Percentage of Students Whose Principals Answered that Policy Goals Were Present

\begin{tabular}{|c|c|c|c|c|c|c|c|}
\hline & $*$ & 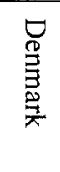 & $\begin{array}{l}\overrightarrow{3} \\
\overrightarrow{3} \\
\underline{\partial}\end{array}$ & $\vec{T}$ & 容 & 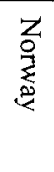 & 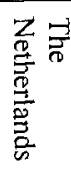 \\
\hline \multirow[t]{2}{*}{ Students use e-mail } & $P$ & $\sim$ & 79 & 53 & 29 & 51 & 34 \\
\hline & LS & 62 & 94 & 50 & 46 & 71 & 62 \\
\hline \multirow{2}{*}{$\begin{array}{l}\text { Students access external databases } \\
\text { via the internet/WWW }\end{array}$} & $\mathrm{P}$ & $\sim$ & 94 & 50 & 25 & 73 & 39 \\
\hline & LS & 84 & 98 & 75 & 72 & 90 & 81 \\
\hline \multirow{2}{*}{$\begin{array}{l}\text { Cooperation with other schools in } \\
\text { the area of computers }\end{array}$} & $\mathrm{P}$ & $\sim$ & 84 & 53 & 54 & 59 & 56 \\
\hline & LS & 50 & 87 & 57 & 58 & 69 & 60 \\
\hline
\end{tabular}

Notes: $* \mathrm{P}=$ primary education; $\mathrm{LS}=$ lower secondary education; $\sim=$ no data available.

Only a third of the principals of primary education in the Netherlands aimed at the use of email by students. Access to external databases was an objective in a relatively small number of primary schools. These percentages were low when compared with other countries, except Italy. The percentages in lower secondary education did not differ much from those of the other countries.

\section{Infrastructure}

An important indicator for the presence of hardware is the number of computers that are available for the students for instructional purposes. This student : computer ratio for each country is shown in Table 2. In the Netherlands the ratio for 1999 is added to Table 2.

In 1998, at Dutch primary schools 1 computer was available for every 22 students. In Finland, Norway and the United Kingdom fewer students needed to share a computer. Though the situation in lower secondary education was more favourable than in primary education for the Netherlands, in the Scandinavic countries the ratio was more favourable. In 1999 the ratio had improved, but probably also in the other countries. 
Table 2: Student : Computer Ratios (median)

\begin{tabular}{|c|c|c|c|c|c|c|c|}
\hline \multicolumn{4}{|c|}{ Primary education } & \multicolumn{4}{|c|}{ Lower secondary education } \\
\hline & Year & 1998 & 1999 & & Year & 1998 & 1999 \\
\hline Finland & & 15.1 & & United Kingdom* & & 9.0 & \\
\hline Norway & & 17.4 & & Denmark & & 10.6 & \\
\hline United Kingdom* & & 18.0 & & Norway & & 11.6 & \\
\hline The Netherlands & & 21.8 & 13.1 & Finland & & 12.4 & \\
\hline France & & 25.1 & & The Netherlands & & 17.1 & 14.6 \\
\hline Italy & & 92.6 & & Italy & & 19.7 & \\
\hline Denmark & & $\sim$ & & France & & 21.0 & \\
\hline
\end{tabular}

Note: $\sim$ no data available; ${ }^{*}=$ data from a national survey in the United Kingdom (DfEE, 1998).

The technology co-ordinators were asked to indicate how many computers for instructional purposes were provided with CD-ROM and a soundcard. For each country the average percentage of computers suited for multimedia application was calculated (see Figure 2).

Figure 2 shows that the Netherlands had a very low percentage of multimedia computers in primary education as well in lower secondary education. Italy had a high percentage of these computers in primary education, but the total number was small.

The availability of specific hardware is also a possible indicator for the functionality of the hardware. In Table 3 the availability of a CD-ROM, a CD-writer, a colour printer and a scanner ("peripherals") in six West-European countries is compared.

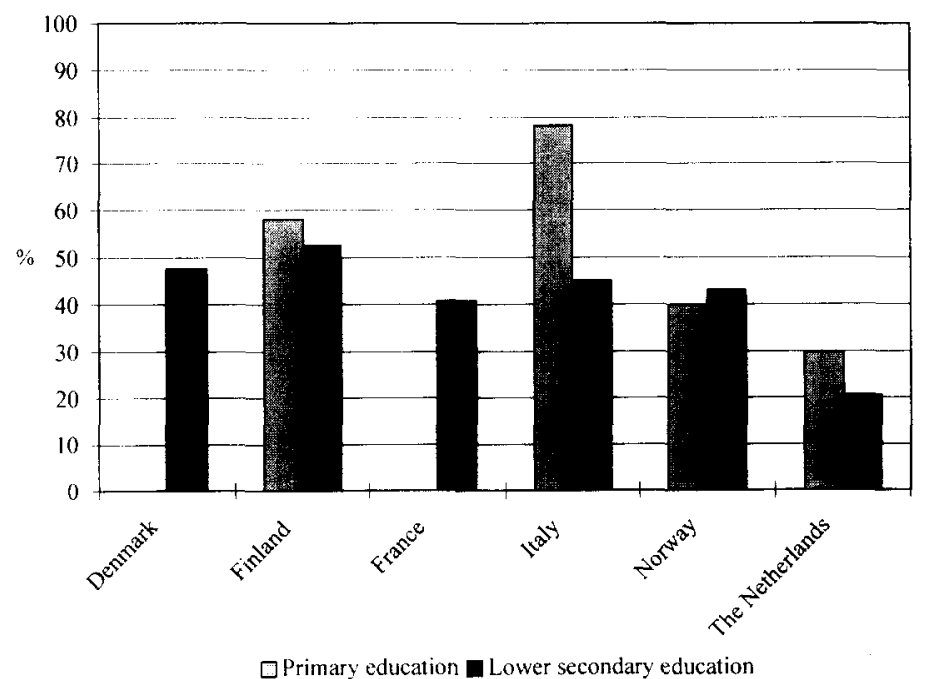

Note: missing bars: data unavailable

Figure 2: Bar Graph of Average Percentages of Multimedia Computers for the Grade Range in Computer-Using Schools in Primary and Lower Secondary Education 
Table 3 shows that schools in Denmark and Finland had a lot of peripherals. When the results in Table 3 are compared for primary education, the Netherlands had the fewest peripherals. For lower secondary education the results were better: here the percentage of available peripherals was comparable with many countries. In 1999 the percentages for the CD-ROM player and colour printer increased in Dutch primary education to $90 \%$ and $65 \%$, respectively, and in lower secondary education to $95 \%$ and $78 \%$ respectively.

Table 3: Percentage of Students Whose Schools had Peripherals

\begin{tabular}{|c|c|c|c|c|c|c|c|}
\hline & * & 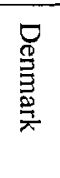 & 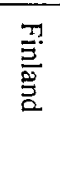 & $\begin{array}{l}\overrightarrow{7} \\
\overrightarrow{8} \\
\overrightarrow{8}\end{array}$ & $\frac{\overline{\vec{\theta}}}{<}$ & $\begin{array}{l}Z \\
\stackrel{0}{Z} \\
\stackrel{2}{*}\end{array}$ & 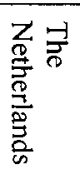 \\
\hline \multirow[t]{2}{*}{ CD-ROM player } & $P$ & $\sim$ & 98 & 80 & 76 & 86 & 69 \\
\hline & LS & 98 & 98 & 97 & 89 & 89 & 89 \\
\hline \multirow[t]{2}{*}{ CD-writer } & $P$ & $\sim$ & 7 & 1 & 26 & 2 & 2 \\
\hline & LS & 78 & 87 & 90 & 77 & 72 & 65 \\
\hline \multirow[t]{2}{*}{ Colour printer } & $P$ & $\sim$ & 73 & 71 & 73 & 72 & 45 \\
\hline & LS & 21 & 19 & 15 & 42 & 6 & 13 \\
\hline \multirow[t]{2}{*}{ Scanner } & $P$ & $\sim$ & 58 & 40 & 66 & 37 & 19 \\
\hline & LS & 94 & 91 & 77 & 74 & 65 & 75 \\
\hline
\end{tabular}

Notes: $* \mathrm{P}=$ primary education; $\mathrm{LS}=$ lower secondary education; $\sim=$ no data available.

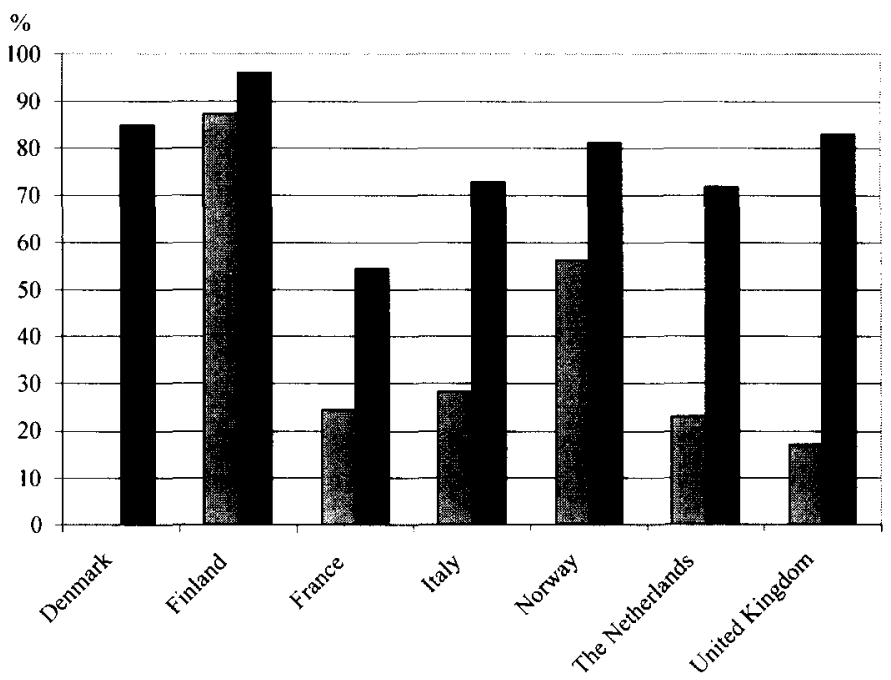

口Primary education $\square$ Lower secondary education

Note: missing bars: data unavailable

Figure 3: Bar Graph of Average Percentages of Computers Accessible at the Grade Range Connected to a Local Network in Primary and Lower Secondary Education 
The technology co-ordinators provided data about the number of computers used for instructional purposes, that is, computers connected to an internal network of the school. A percentage per school was calculated. Figure 3 shows the average percentages of computers in an internal network per country.

In the Netherlands many computers were connected to an internal network, both in primary education and lower secondary education. The results for the Netherlands were comparable with the results for Finland.

Over the past several years the use for instructional purposes of the internet and the World Wide Web in school has become important. Schools were asked to indicate whether they had access to the internet. Figure 4 shows the percentages per country.

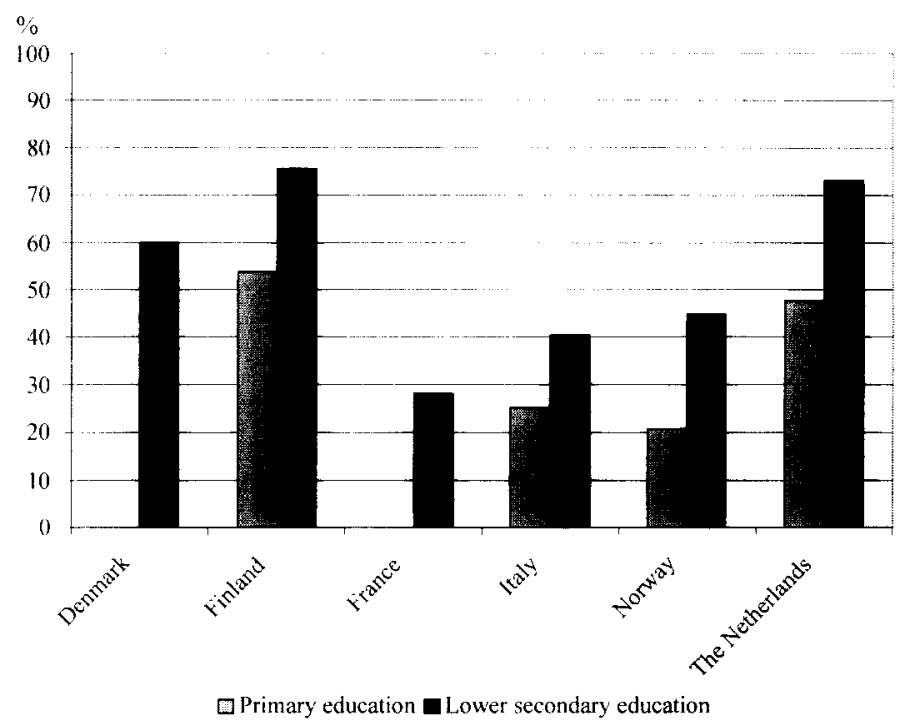

Note: missing bar: data unavailable

Figure 4: $\quad$ Bar Graph of Percentages of Students Whose Schools had Access to the Internet for Instructional Purposes in Primary and Lower Secondary Education

In all countries more schools in lower secondary education had access to the internet. The percentage for primary education in the Netherlands was one of the lowest. The percentage of lower secondary education in the Netherlands was comparable with Denmark and Norway. In 1999 the percentage in Dutch primary education increased to $38 \%$ and in lower secondary education to $86 \%$.

\section{Staff Development}

The principals of the schools were asked to provide information on the policy of the school regarding in-service training and to what extent the schools had realised this policy. Table 4 shows the results.

In the Netherlands, in nearly three-quarters of the primary schools the policy concerning staff development was aimed at in-service training for all teachers. This had 
been realised almost or fully at $2 \%$ of the schools. One year later it was realised in $3 \%$ of the schools. For lower secondary education the results were slightly better than for primary education. In 1999, nearly all schools wanted in-service training for all teachers. Only in $12 \%$ of the schools this policy goal was realised.

Table 4: Percentages of Students Whose Principals Indicated School Adopted Teacher Training Goals and Percentages Reflecting Realization of Goals, in Primary and Lower Secondary Education

\begin{tabular}{lcccccccc}
\hline & \multicolumn{3}{c}{ Primary education } & \multicolumn{3}{c}{ Lower secondary education } \\
& \multicolumn{2}{c}{ All teachers } & Few teachers & \multicolumn{2}{c}{ All teachers } & \multicolumn{2}{c}{ Few teachers } \\
& Goal & Realised & Goal & Realised & Goal & Realised & Goal & Realised \\
\hline Denmark & $\sim$ & $\sim$ & $\sim$ & $\sim$ & 85 & 19 & 88 & 60 \\
Finland & 97 & 32 & 87 & 35 & 98 & 31 & 94 & 38 \\
France & 73 & 3 & 57 & 5 & 82 & 5 & 87 & 20 \\
Italy & 86 & 23 & 72 & 32 & 90 & 14 & 75 & 22 \\
Norway & 95 & 20 & 86 & 38 & 97 & 24 & 88 & 47 \\
The Netherlands '98 & 72 & 2 & 88 & 19 & 94 & 4 & 87 & 18 \\
The Netherlands '99 & 78 & 3 & 91 & 27 & 97 & 12 & 93 & 35 \\
\hline
\end{tabular}

Note: $\sim$ no data available

The results for the Netherlands are the lowest when compared with the other countries (realisation of in-service training for all teachers as well as some teachers).

Transfer of information is an important condition to the implementation of an innovation. Schools can have structured ways for transferring information. In Table 5 the results for some of these possibilities are shown.

Table 5: Percentages of Students at Schools with Arrangements for Transfer of ICT Knowledge Among Teachers, in Primary and Lower Secondary Education

\begin{tabular}{|c|c|c|c|c|c|c|c|}
\hline & $*$ & 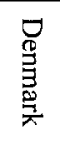 & 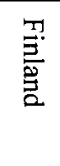 & 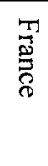 & 焉 & 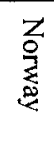 & 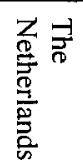 \\
\hline Via informal contacts & $\begin{array}{l}\text { P } \\
\text { LS }\end{array}$ & $\tilde{92}$ & $\begin{array}{l}57 \\
67\end{array}$ & $\begin{array}{l}76 \\
86\end{array}$ & $\begin{array}{l}52 \\
74\end{array}$ & $\begin{array}{l}86 \\
87\end{array}$ & $\begin{array}{l}91 \\
93\end{array}$ \\
\hline Via technology co-ordinator & $\begin{array}{l}\text { P } \\
\text { LS }\end{array}$ & $\tilde{78}$ & $\begin{array}{l}73 \\
72\end{array}$ & $\begin{array}{l}26 \\
43\end{array}$ & $\begin{array}{l}38 \\
44\end{array}$ & $\begin{array}{l}69 \\
73\end{array}$ & $\begin{array}{l}90 \\
64\end{array}$ \\
\hline Via school's ICT working group & $\begin{array}{l}\text { P } \\
\text { LS }\end{array}$ & $\underset{23}{\sim}$ & $\begin{array}{l}9 \\
7\end{array}$ & $\begin{array}{l}2 \\
7\end{array}$ & $\begin{array}{l}40 \\
32\end{array}$ & $\begin{array}{l}15 \\
16\end{array}$ & $\begin{array}{l}20 \\
27\end{array}$ \\
\hline Via in-school courses & $\begin{array}{l}\text { P } \\
\text { LS }\end{array}$ & $\widetilde{63}$ & $\begin{array}{l}50 \\
45\end{array}$ & $\begin{array}{c}7 \\
18\end{array}$ & $\begin{array}{l}57 \\
72\end{array}$ & $\begin{array}{l}47 \\
61\end{array}$ & $\begin{array}{c}9 \\
20\end{array}$ \\
\hline No organised structure & $\begin{array}{l}\text { P } \\
\text { LS }\end{array}$ & $\sim$ & $\begin{array}{l}12 \\
14\end{array}$ & $\begin{array}{l}42 \\
44\end{array}$ & $\begin{array}{l}18 \\
18\end{array}$ & $\begin{array}{l}28 \\
22\end{array}$ & $\begin{array}{l}43 \\
49\end{array}$ \\
\hline
\end{tabular}

Notes: ${ }^{*} \mathrm{P}=$ primary education; $\mathrm{LS}=$ lower secondary education; $\sim=$ no data available. 
In Dutch primary education information was transferred mostly by informal contacts and by the technology co-ordinator. In lower secondary education the informal contacts were also important.

The transfer of information in the other countries did not differ much from the Netherlands, though transfer via in-school courses was important in countries like Denmark, Finland, Italy and Norway. ICT working groups were not popular in Finland and France.

\section{Attitudes, Policies and Usage at Managerial Level}

The principal of a school is regarded as a key-person when it comes to the implementation of an innovation. His or her attitudes towards several aspects related to ICT are of great importance. Table 6 shows the results for four aspects: (a) the relevance of the internet, (b) in-service ICT training compulsory, (c) digital driving licence, and (d) ICT in education.

Table 6: Average Values of Principals' Attitudes Towards ICT in Primary and Lower Secondary Education

\begin{tabular}{lcccccccc} 
& \multicolumn{3}{c}{ Primary education } & \multicolumn{4}{c}{ Lower secondary education } \\
& $\mathrm{a}^{*}$ & $\mathrm{~b}$ & $\mathrm{c}$ & $\mathrm{d}$ & $\mathrm{a}$ & $\mathrm{b}$ & $\mathrm{c}$ & $\mathrm{d}$ \\
\hline Denmark & $\sim$ & $\sim$ & $\sim$ & $\sim$ & 89 & 89 & 87 & 81 \\
Finland & 87 & 73 & 50 & 73 & 91 & 66 & 47 & 74 \\
France & 74 & 75 & 68 & 71 & 77 & 78 & 73 & 74 \\
Italy & 84 & 85 & 82 & 85 & 88 & 88 & 79 & 85 \\
Norway & 79 & 92 & 73 & 77 & 84 & 91 & 70 & 78 \\
The Netherlands & 66 & 71 & 77 & 68 & 74 & 77 & 80 & 73 \\
\hline
\end{tabular}

Notes: $a=$ the relevance of the Internet, $b=$ in-service ICT training compulsory, $c=$ digital driving licence, $\mathrm{d}=$ ICT in education; $\sim=$ no data available.

The Dutch principals of primary schools attached the least importance the internet, compulsory in-service training and ICT in education, compared to the other countries. They take the view that the digital driving licence is the most important. Attitudes towards the four above-mentioned aspects related to ICT did not much differ between Dutch principals and their colleagues elsewhere in lower secondary schools.

The use of ICT in a school can result in the development of a common vision on the use of computers in education and to consideration of norms and values in using the internet/WWW. Table 7 shows the percentage of schools that have adopted these goals and to what extent they have realised these goals. In the Netherlands, the development of a common vision on the use of ICT was a goal of many schools in primary and lower secondary education. The percentages were higher than in the other countries. In 1999 nearly all schools for lower secondary education had adopted this goal. The realisation of this goal in the Netherlands is about average.

Half of the schools in primary education and three quarters of the schools in lower secondary education paid attention to norms and values in using the internet/WWW. These percentages were lower than in several other countries. In 1999 these percentages increased. 
Table 7: Percentages of Students Whose Principals Indicated (i) School's Common Vision on Computer Use and Attention to Norms and Values in Use and (ii) Goals not Realised, in Primary and Lower Secondary Education

\begin{tabular}{lcccccccc}
\hline & \multicolumn{3}{c}{ Primary education } & \multicolumn{3}{c}{ Lower secondary education } \\
& $\begin{array}{c}\text { Common vision } \\
\text { Goal }\end{array}$ & $\begin{array}{c}\text { Norms \& values } \\
\text { realised }\end{array}$ & Goal & $\begin{array}{c}\text { Not } \\
\text { realised }\end{array}$ & Goal & $\begin{array}{c}\text { Not } \\
\text { realised }\end{array}$ & Goal & $\begin{array}{c}\text { Not } \\
\text { realised }\end{array}$ \\
\hline Denmark & $\sim$ & $\sim$ & $\sim$ & $\sim$ & 58 & 34 & 73 & 21 \\
Finland & 91 & 26 & 95 & 13 & 89 & 32 & 98 & 6 \\
France & 77 & 55 & 54 & 82 & 79 & 57 & 78 & 51 \\
Italy & 75 & 36 & 46 & 55 & 69 & 41 & 72 & 34 \\
Norway & 69 & 60 & 57 & 74 & 69 & 58 & 74 & 51 \\
The Netherlands '98 & 88 & 40 & 51 & 90 & 94 & 35 & 75 & 62 \\
The Netherlands '99 & 88 & 32 & 55 & 71 & 99 & 11 & 84 & 44 \\
\hline
\end{tabular}

Notes: $\sim=$ no data available

The principals of the schools were asked whether keeping track of student's learning progress was a policy goal and to what extent computers are used for this goal. Table 8 shows the results.

Table 8: Percentage of Students Whose Principals Indicated Extent of Use of Computers to Keep Track of Students' Learning Progress, in Primary and Lower Secondary Education

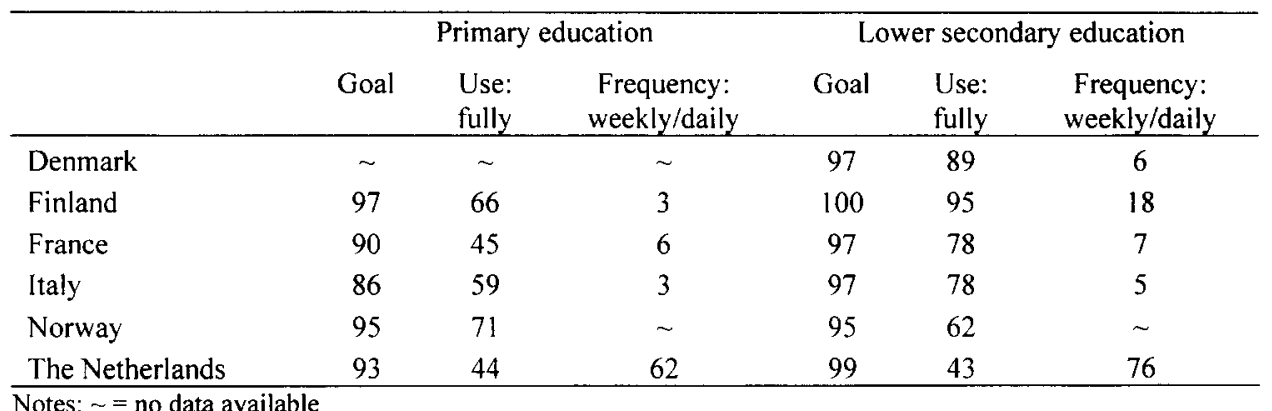

In all countries, in most or nearly all of the schools the use of the computer for keeping track of students' learning progress was a policy goal. Though this percentage for the Netherlands did not differ from the other countries, the realisation of this goal in the Netherlands was far behind these countries. There is no difference between primary education and lower secondary education. In the Netherlands the computer was used for this activity mainly on a weekly or daily basis. 


\section{Further Analysis}

In the preceding sections the results on several indicators for a number of countries, which participated in Module 1 of the SITES-project, are presented and compared. It is difficult to compare the countries. It is impossible to point at one particular country as having done best on all indicators. Sometimes, a country has the highest score on one indicator, but a low score on another. This applies for both populations. The countries differ too much on these indicators.

An alternative is ranking each country on a number of criteria. The total of these rankings, based on all criteria, yields the position of each country. For this ranking the results presented in the tables and figures in this article are used. Most of the criteria are based on two or more indicators, depending on the number of indicators in the Tables and Figures. A country that has the highest score on a criterion gets the highest rank. The results of Figure 2 and Figure 3 for primary education were left out because no data are available for France. In lower secondary education the results of these figures are combined with those in Table 3 and Figure 4 respectively. These two criteria are based on two indicators each.

To calculate the total ranking, the rankings of the ten criteria were summed. The country that has the highest sum gets the highest total ranking. The results are shown in Figure 5 for both populations separately. The last column in each graph shows the total ranking of these countries.

Figure 5 shows that in both populations Denmark (only in lower secondary education), Finland and Norway have the highest positions, whereas the Netherlands and France have the lowest positions in this ranking. Some countries show nearly the same pattern in both populations (e.g., France and the Netherlands) with regard to the ten criteria, while some other countries (e.g.. Norway and Italy) have different patterns.

Though this ranking gives a good impression of the state of affairs in these countries. it is regrettable that there are no data available for all indicators from other WestEuropean countries, like Germany, the United Kingdom, Belgium and Spain. This would have made this ranking more meaningful. $A$ disadvantage of this ranking method is that the differences in distances between the scores on an indicator are neglected. By weighting to the separate rankings, it is possible to account for these differences in distances.

Looking at some indicators in greater detail, it is possible to give qualifications to them, taking into account the position of the Netherlands for that particular indicator in comparison with the other West-European countries. With these qualifications the policies on ICT in the Netherlands can be evaluated. In Table 9 the results are summarised by giving a qualification for the Netherlands for these indicators. The qualifications range from good to bad. 
Primary education

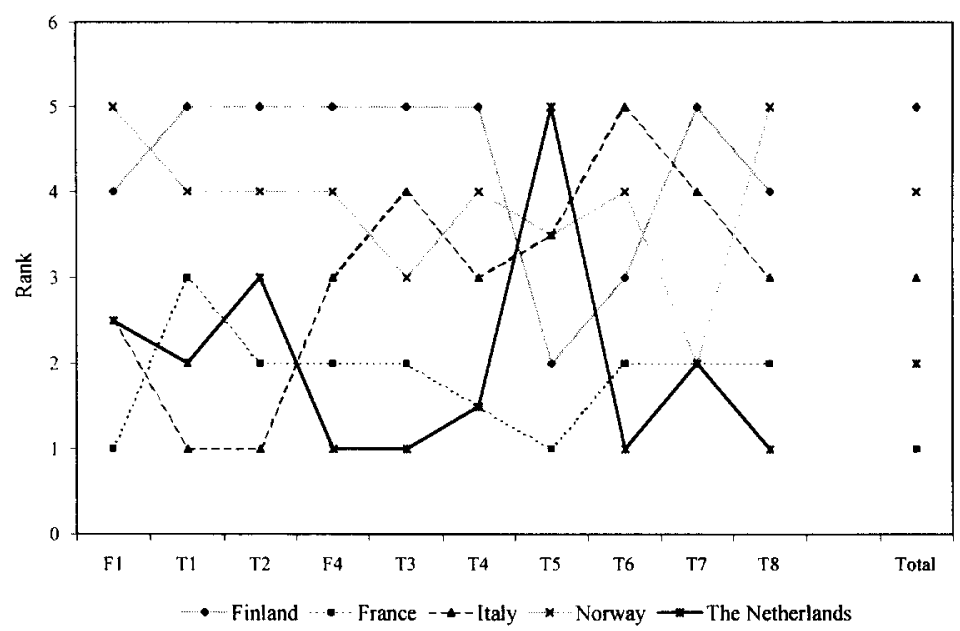

Lower secondary education

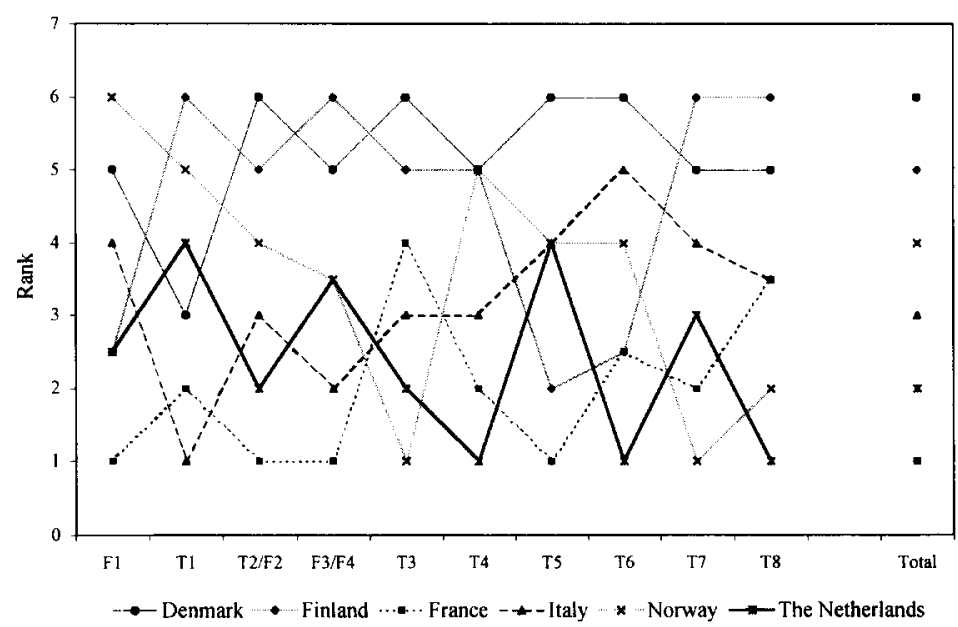

Figure 5: Ranking of the Countries on Ten Criteria and the Total Ranking in Primary and Lower Secondafy Education 
Table 9: Qualifications on a Number of ICT-Indicators for the Netherlands in 1998, Based on a Comparison with Other Countries

\begin{tabular}{lc}
\hline \multicolumn{2}{c}{ Primary education } \\
ICT-indicator & Qualification \\
\hline Student : computer ratio & Poor \\
Multimedia computers & Bad \\
Internal network & Good \\
Peripherals & Bad \\
Access to internet & Bad \\
Realised training of teachers & Bad \\
\hline
\end{tabular}

Lower secondary education

\begin{tabular}{lc} 
ICT-indicator & Qualification \\
\hline Student : computer ratio & Moderate \\
Multimedia computers & Bad \\
Internal network & Good \\
Peripherals & Good \\
Access to internet & Moderate \\
Realised training of teachers & Bad \\
\hline
\end{tabular}

Table 9 shows that the Netherlands is not doing so well on a number of indicators. Lower secondary education is doing better than primary education. This is also expressed in Figure 5 although combining two or more indicators into one criterion has reduced the differences. The qualification bad in primary education for the indicator Access to the Internet is equal to the low rank on criterion $\mathrm{F} 4$ (Figure 5). The situation in lower secondary education is better: criterion F3/F4 shows that the Netherlands ranks higher than both Italy and France. For the indicator Realised training of teachers the qualification bad is given in Table 9. In Figure 5, the Netherlands has the lowest ranking on T4.

\section{Conclusions}

In this article several West-European countries were compared with each other on a number of indicators with regard to the state of affairs related to ICT. It can be concluded that none of these countries scores highest on all indicators, though the Scandinavian countries have high scores for many indicators.

By ranking these countries on a number of criteria, it can be concluded that Denmark (only in lower secondary education) and Finland rank highest in both populations. Altogether, these countries have a more favourable state of affairs related to ICT than the other participating countries. France has the least favourable state of affairs. The Netherlands has a low position in this ranking. This can be understood when the qualifications that are given for some indicators are taken into account. The qualifications also reflect the position of the Netherlands compared to other countries. It should be noted that the state of affairs related to ICT is better in lower secondary education than in primary education.

From the qualifications that are give to some indicators it can be concluded that policy of the Dutch government has not yet reached it goals. Especially in primary education hardware and access to the internet are problematic. The training of teachers is unacceptable in both populations.

For some ICT-indicators the results of 1998 and 1999 are presented for the Netherlands. The results of 1999 are better than the results of 1998, as may be expected. But the results of 1999 do not show that the Netherlands has covered much ground. Schools 
in other countries have also progressed, e.g., bought new hardware. Therefore, it can be assumed that the student : computer ratio also has improved in these countries, too.

\section{Discussion}

The government has decided to enlarge its role in creating the right conditions for the professional development of teachers with regard to ICT. An additional condition for improving teacher training could be to relieve the teachers from their teaching tasks over a certain period, for a certain time per week and use this time for training. At this moment schools have made plans, and maybe made arrangements with training institutes for training after school hours. The teachers regard this training as an extra task. Organising training during school hours, exclusively or for the most part, would reflect more sympathy with the teachers. Therefore it is recommended to integrate the professional development in teachers' daily activities. Once teachers are trained to use hardware and software and have the basic skills, the need for more and better hardware will increase. Only then the investments would be meaningful.

Another aspect related to the training of teachers needs attention, i.e., the content of the training courses. Technical training in ICT (how to use a computer, how to use a word processor and how to use the internet) is not sufficient. In most of the training the emphasis is on the technical aspect, but the educational aspect (how to use hardware and software in the daily educational practice) is omitted. A digital-driving license is not enough. Teachers need to know how to use computers in education; otherwise innovative educational practices cannot be realised in the schools. It is recommended to emphasise the educational aspect and pay less attention to the technical aspects. The European Computer Driving License has set goals, which go beyond what a teacher needs in his or her daily practice.

Another problem is access to the internet in primary education. The Dutch government has the policy to connect all schools to the educational network Kennisnet. The network will be successful when the present technical problems are solved. Next, the available information and materials for schools have to appealing to the teachers. If this is not the case, the network will have no added value compared to an internet service provider. Therefore, it is recommended that Kennisnet becomes, as soon as possible, an interesting and worthy source of information for teachers. In connection to this, sufficient measures should be taken to guarantee safe access to and use of the internet.

These recommendations are relevant for the Netherlands. Perhaps they are relevant for other countries too. This depends on the state of affairs related to ICT and the policies on ICT of the government in these other countries. Both give indications what is needed in a particular country. The common goal is to prepare their schools and their pupils for the information society of the 21 st century.

\section{Note}

1. In the Netherlands Module 1 of the SITES-project was carried out by the Centre for Applied Research in Education (OCTO) of the University of Twente, under the auspices of the IEA. The Dutch contribution to the SITES-project was funded by the Dutch Organisation for Scientific Research (NWO). 


\section{References}

Doornekamp, B.G. (2000). ICT-indicatoren voor het Nederlandse onderwijs in internationaal perspectief [ICT-indicators for Dutch education in international perspective]. Enschede: Universiteit Twente - OCTO.

Doornekamp, G., \& Drent, M. (1999). National ICT related policies - The Netherlands. In W.J. Pelgrum \& R.E. Anderson (Eds.), ICT and the emerging paradigm for life long learning: a worldwide educational assessment of infrastructure, goals and practices (pp. 68-70). Amsterdam: IEA.

Department for Education and Employment (DfEE). (1998). Survey of information and communication technology in school 1998. London: Government Statistical Service.

Drent, M., Ten Brummelhuis, A., \& Plomp, Tj. (in preparation). In Tj. Plomp, R. Anderson, N. Law \& A. Quale (Eds.), Cross national policies and practices on ICT in education (in preparation).

Information Society Index (ISI). (2001). [On-line] Available: Http://www.worldpaper.com/ $2001 / \mathrm{jan} 01 / \mathrm{ISI} /$.

Ministerie van Onderwijs, Cultuur en Wetenschappen (MOC\&W) [Ministry of Education, Culture and Science]. (1997). Investeren in voorsprong: het actieplan [Investing in staying ahead: The plan for action]. The Hague: SDU.

Ministerie van Onderwijs, Cultuur en Wetenschappen (MOC\&W) [Ministry of Education, Culture and Science]. (1999). Onderwijs on line: Verbindingen naar de toekomst [Education on line: Connections to the future]. The Hague: SDU.

Pelgrum, W.J., \& Anderson, R.E. (Eds.). (1999). ICT and the emerging paradigm for life long learning: a worldwide educational assessment of infrastructure, goals and practices. Amsterdam: IEA.

Pelgrum, W.J., \& Plomp, Tj. (1991). The use of computers in education worldwide: Results from the IEA 'Computers in Education' survey in 19 educational systems. Oxford: Pergamon.

Pelgrum, W.J., \& Plomp, Tj. (1993). The use of computers in education in 18 countries. Studies in Educational Evaluation, 19 (2), $101-125$.

RM G7. (1999). The RMG7 report 1998: ICT provisions in schools. Abingdon, UK: RM.

Ten Brummelhuis, A.C.A. (1998a). ICT-monitor 1997-1998. Basisonderwijs [ICT-monitor 19971998. Primary Education]. Enschede: Universiteit Twente - OCTO.

Ten Brummelhuis, A.C.A. (1998b). ICT-monitor 1997-1998. Voortgezet Onderwijs [ICT-monitor 1997-1998. Secondary Education]. Enschede: Universiteit Twente - OCTO.

Ten Brummelhuis, A.C.A., \& Drent, M. (2000). ICT-monitor 1998-1999. Basisonderwijs [ICTmonitor 1998-1999. Primary Education]. Enschede: Universiteit Twente - OCTO.

Ten Brummelhuis, A.C.A., \& Slotman, K.M.J. (2000). ICT-monitor 1998-1999. Voortgezet Onderwijs [ICT-monitor 1998-1999. Secondary Education]. Enschede: Universiteit Twente - OCTO.

\section{The Author}

GERARD DOORNEKAMP is working as an educational researcher at the Faculty of Educational 
Science and Technology of the University of Twente, the Netherlands. He was the National Research Co-ordinator (NRC) for the Netherlands of Module 1 of the "Second Information Technology in Education Study" (SITES) and is now the NRC for Module 2 of SITES. He is also the National Research Expert for the Netherlands of the "Case Studies of Organisational Change" of the Organisation of Economic Co-operation and Development (OECD).

Correspondence: <doornekamp@edte.utwente.nl> 